\title{
The Impact of the Internal Audit on the Quality of Accounting Information in the Jordanian Commercial Banks
}

\author{
Abdul Razzak Al-Chahadah ${ }^{1}$, Mohammed Zakaria Soda ${ }^{2}$ \& Rania Al Omari ${ }^{3}$ \\ ${ }^{1}$ Department of Accounting, Faculty of Business, Al-Zaytoonah University of Jordan, Jordan \\ ${ }^{2}$ Department of Accounting, Faculty of Business, ISRA University in Jordan, Jordan \\ ${ }^{3}$ Department of Accounting, Faculty of Business and Finance, University of Jordan, Jordan \\ Correspondence: Mohammed Zakaria Soda, Department of Accounting, Faculty of Business, ISRA University in \\ Jordan, Amman 11622, Jordan.
}

Received: July 5, 2018

Accepted: August 20, 2018

Online Published: August 30, 2018

doi:10.5539/ijef.v10n9p157

URL: https://doi.org/10.5539/ijef.v10n9p157

\begin{abstract}
Internal Audit is deemed an important issue of controversy and development in terms of concept, objectives, domain, scope of work or performance criteria due to the fundamental developments that occur in the environment surrounding the financial institutions, as well as in the concepts and entry points of other sciences associated with internal audit, in particular, the concepts of accounting information quality and its methods and advanced administrative trends which require internal audit to perform professional services to help the accounting unit management to produce high quality of financial statements that can be credible for those who are interested in the economics of the financial institutions.
\end{abstract}

Keywords: internal audit, accounting information quality, appropriate accounting information, the credibility of accounting information, commercial banks of Jordan

\section{Introduction}

\subsection{The Problem of the Study}

The problem of the study is to verify to what extent the internal audit have impact on the production of relevant and credible accounting information, because of the importance of the internal audit function in one hand and the risk of relying on misleading accounting information and numbers in other hand, which is negatively reflected on the decisions of those interested in corporate economics. Improving the qualitative characteristics of the financial statements information in the companies is deemed one of the main objectives of IFRS \#7 and the disclosure rules contained therein. The data contained in the financial statements are considered to be the major sources of current and potential users to determine their attitudes towards the corporate activities and decision making.

The problem of the study can be summed up by answering the two following questions:

1) What is the impact of internal audit procedures on the credibility of accounting information contained in the financial reports of the Jordanian commercial banks?

2) What is the impact of internal audit procedures on the relevance of accounting information to the financial reports in the commercial banks of Jordan?

\subsection{Objectives of the Study}

This study aims to achieve the following objectives:

1) The demonstration of the impact of internal audit procedures on the credibility of accounting information contained in the financial reports in the commercial banks in Jordan.

2) The demonstration of the impact of internal audit procedures on the relevance of accounting information to the financial reports in the commercial banks in Jordan.

\subsection{The Study Hypotheses}

HO1: There is no statistically significant impact of internal audit procedures on the credibility of the accounting information contained in the financial reports of the commercial banks in Jordan. 
HO2: There is no statistically significant impact of internal audit procedures on the relevance of the accounting information contained in the financial reports of the commercial banks in Jordan.

\section{Methodology}

This study relies on the descriptive analytical accounting approach adopted by the accounting literature to build the conceptual framework of the study, represented in the impact of the internal audit on the quality of accounting information. The data have been studied and analyzed, and the variables of this study was made through converting the qualitative variables into measurable quantitative variables in order to deal with them in testing the hypotheses and the show the results of the study and its recommendations.

\section{Previous Studies}

First, the Study of soda and Al-Chahadah (2017), entitled "The Balanced Scorecard as a Strategic Introduction to the Commercial Banks Performance Assessment in Jordan" aims to find out the preferable measurements of performance assessment in the commercial banks in Jordan, identify the factors that impact their performance assessments, as well as to determine the capacity of Jordanian commercial banks to develop and implement a financial and non-financial strategy by using the balanced scorecard approach. The descriptive analytical approach has been used based on the field study to obtain the data from its main sources, the validity of hypotheses have been tested and got answers to the study questions. The study concluded that the Jordanian commercial banks do not use the balanced scorecard as an approach assisting to formulate, implement and evaluate a financial and non-financial strategy. This indicates that these banks tend to use traditional assessment instruments, not the modern ones, although the study community members acknowledged the importance of this tool in evaluating the results of bank financial and nonfinancial operations of these banks. And One of the most important recommendations is that the Jordanian commercial banks must adopt the balanced scorecard approach in their financial and non-financial evaluation process, due to the multifaceted alternatives and uses of this methodology in the performance evaluation and to rationalize the decisions of decision makers based on objective measurement indicators carefully selected to achieve the bank's mission.

Second, the study of Lawrence J. Abbott et al. (2016), entitled "Internal Audit Quality and Financial Reporting Quality: The Joint Importance of Independence and Competence" examines an interactive model of IAF quality (comprised of competence and independence) to better understand the determinants of IAF effectiveness as a financial reporting monitor. The tests support the hypothesis that the joint presence of competence and independence is a necessary antecedent to effective IAF financial reporting monitoring. sum results show that, the answer to "what is the effect of internal audit competence (independence) on financial reporting quality?" is "it depends on the independence (competence) of the internal auditor."

Third, the study of Gras-Gil et al. (2012), entitled "Internal audit and financial reporting in the Spanish banking industry" tested the relationship between a firm's internal audit function (IAF) and the quality of its financial reporting. Since regulations on corporate governance were introduced, numerous national and international bodies have emphasized the fundamental role of the IAF in the financial reporting process, especially since it generally leads to higher quality reporting. The study concluded that the Banks with high quality financial reporting have greater collaboration between internal and external auditors in the annual audit. Greater involvement of internal audit in reviewing financial reporting leads to improved quality financial reporting.

\section{Theoretical Framework}

\subsection{The Concept and Definition of Internal Auditing}

The modern concept of internal audit has two functions, namely: (al-Wardat, 2014, 36)

- Attestation services: the services that are concerned in the objective evaluation of the evidence to provide an independent opinion or conclusions pertinent to the process or system and other subjects; the nature, scope, and task of attestation are determined by the internal auditor.

- Consultancy services: they are the consultancy services provided to regulatory units in and out of the enterprise. The nature and scope of these processes are determined by the agreement with such corporates. The purpose of such services is to add a value to the unit and improve its operations.

The international Auditing Standard \# 610 has defined internal audit as "an evaluation activity arising within the enterprise for the purpose of serving it. The functions of internal audit include testing, evaluating, and controlling the efficiency, relevance and effectiveness of the accounting system used and internal auditing system". (IFAC, 2010, 627).

The USA Institute of Internal Auditors (IIA) defines internal audit as an independent, objective and advisory 
activity designed to add value to the organization and improve its operations. Auditing assists the organization to achieve its objectives through adopting a substantive and structured input to evaluate and improve the effectiveness of risk management, control, and control operations. (al-Wardat 2014, 74).

\subsection{Internal Auditing Procedures}

The effective internal audit procedures are determined by five key consecutive actions. The personnel of internal audit activity have to adhere to and work accordingly. The internal auditing procedures are:

\subsubsection{Planning of Internal Audit}

The internal auditor has to plan the audit process, so as to mitigate the risk of auditing to obtain a reasonable assurance on adequacy and relevance of evidence to support his conclusions. The internal auditor has to conduct an assessment to the auditing risk and use such assessment to determine the auditing objectives, scope and the method that should be followed to achieve these objectives efficiently. (al-Agha, 2015, 44).

Al-Mar'ie defined internal audit planning process as a set of actions that involve formulating objectives and strategies of auditing process. It links internal audit objectives with the organization objectives, so as to help Internal Audit Department to work in the best possible effectiveness. (al-Mar'ie, 2009, 45).

Planning of audit activity includes the need to develop objectives and identify the scope of work. It also conditioned to obtain sufficient information to form a background on the activities to be audited, identifying the resources necessary to perform auditing, communicating with those who are involved in auditing as well as that activities subject to the audit. Sometimes, it is necessary to conduct a survey in order to identify the activities, risks and control procedures, so we can identify the aspects that need more attention, conducting additional tests during auditing process, writing down the auditing programs, identifying how to send and to whom the results of auditing are to be sent. Finally obtaining the consent of the Internal Auditing Supervisor on the work plan of auditing. (al-Mar'ie 2009, 55).

\subsubsection{Verification and Assessment of Activities and Processes}

Verification and assessment function is deemed an extension of the compliance, and to include all the financial events in the financial statements and accounting records. So, the concept of verification and assessment includes ensuring that every part of the organization activities is subject to the control of internal audit and internally audited. Therefore, the achievement of this internal procedure by the auditor will be made through the establishment of internal audit program through the organization chart of the organization rather than through the financial reports. Based on the foregoing, the internal auditor, in such case, is deemed a representative of the senior management because he evaluates the extent of convergence objectives of subsystems with the objectives set by the senior management or the extent of consistent between the system and the requirements of the management. (Arens, 2003, 379)

\subsubsection{Report and Communication on Audit Activities}

The internal auditor's report is an important and central tool used by the external auditor to help him to assess the internal control system, determine the extent of his auditing job, and guide him where the problems are concentrated besides the important areas that need to be deeply examined more than others. (Sawafiri, 2002, 233).

No doubt that the purpose of the internal auditor's report, as a product of verification, testing, and evaluation processes, is to provide information for decision makers on time, and ensure that the information is clear and reflects the real situation of the organization. Undoubtedly, the internal audit department bears many responsibilities towards decision makers as being responsible for the achievement of internal control goals which includes the control of efficiency and effectiveness of operations, the control of the financial reports and compliance control. (Abu Zir 2006, 76).

\subsubsection{Follow-Up, Development and Evaluation of the Results}

Internal audit is a feedback tool. As it tests and evaluates the operations and existing activities, it may produce several recommendations that serve as inputs to be re-operated by the senior management to produce new alternative or newly created recommendations, which may positively affect the pertinent operations and activities. This confirms that the results of internal audit activities can be used as a feedback to modify and develop the plans and take advantage of the past mistakes. (al-Afifi, 2007, 28).

The internal audit report serves as a tool for evaluating the operational performance. It also deemed a window for the operational managers to express their views and actions, in addition to motivation of the operational departments' personnel and senior management to raise subjects where the managers refrain to do so because of their apprehension of regulations routine. (Sawafiri, 2002, 243). 


\subsubsection{Coordination and Cooperation with the External Auditor}

The relationship between internal and external auditing is complementary. There are a lot of factors affecting this relationship, including the role of the Audit Committee by encouraging cooperation between the internal and external auditor, regular consultancy, and the existence of effective communication channels between the internal and external auditors besides mutual professional confidence and compliance to quality of work. (Fowzia, 2010, 27).

The importance of Integration and cooperation between the two parties plays a role in achieving quality and effectiveness to both parties, as well as organization because the internal auditor practices the backward and forward control through his daily presence in the organization, having acquainted to the plans, regulations and implementing mechanism of such plans and regulations. The external auditor practices the subsequent control only because his visits to the organization to perform specific auditing task, usually after the execution of works. (Abu Sar'ah, 2010, 132).

\section{Quality of Accounting Information}

The Publication No 2 of the Financial Accounting Standards Board (FASB) identified the qualitative characteristics of accounting information where it is possible accordingly to focus on the most useful information and the less useful for the purpose of decision making. Information users are the starting point in determining the characteristics of the information because the users are different with multi interests, that is, there is a contradiction and variation in their motives. Consequently, it will result to decisions that vary according to their objectives. Information should be understandable, which are the presumed features in the information users (decision makers). The information must to be provided so that individuals, with reasonable knowledge of business and economic and accounting activities, can study and understand such information and be able to use them. This is what is called understandability. (Richard, 2006, 138).

The basic information characteristics that will make accounting information useful to users are relevance characteristic, reliability characteristic or dependability characteristic. Thus, the financial reporting must be adequate and reliable. Many accounting literature indicated that reliability is deemed a prerequisite that must be met in the information to be appropriate for decision making. (DeLone \& Mclean, 2008), the auditor specialization effect of accounting information quality.(Elaoud, 2017, 616).

The professional bodies issues the accounting standards measure the quality of accounting information mainly by its ability to assist investors and lenders to estimate the ability of the organization to generate in future cash flow sufficient to meet its obligations on maturity, besides its ability to provide regular cash distributions to the investors without affecting its production level and its ability to grow. (Nadhier 2014, 54).

The researchers monitored the concepts of accounting information quality issued by the international professional societies and the basic characteristics of useful accounting information. The most important characteristics are:

\subsection{Relevance}

Relevance is one of the most important characteristics that should be found in information reflected in the financial reports and financial statements of the companies listed in the capital markets. It means that the accounting information should be able to change the decision of the information user and influence him; i.e. it is the accounting information ability to influence the decision making. Once the information had no effect on a particular decision, it would be inadequate to that decision. In the sense that for information to be relevance, it must support or not support the expectation of the decision maker. (Wasfi 2010, 31).

Relevance feature can be achieved through the following: (Nadhier 2014, 52).

- Up-to-date Information and available on time (i.e. appropriate time)

- Enabling the decision maker to improve his future expectations of the results of events, that is, the ability to predict the future.

- Helps the decision maker to review and correct previous expectations.

Relevance is one of the basic qualitative characteristics that make the accounting information useful in economic decision making. The information must affect or make difference in the decision to be considered relevant for making economic decision. It helps the financial reporting users to predict the future through the reading the past, current and future results, i.e. it means that this feature has a predictive as well as a feedback value. Therefore, it must be available to users on time. (Keiso, Weygandt, \& Warfield, 2005, 32).

The appropriate accounting information enables its users to: (Addayeh, 2009, 46). 
1) Create expectations about the results will ensue on the past, current and future events.

2) Enhance current expectations or make a difference in these expectations.

3) Improve decision maker's ability to predict expected future results and to enhance or to correct past and current expectations.

4) Evaluate the results of the decisions that have been based on these decisions.

\subsection{Dependability and Credibility}

Dependability is deemed the second fundamental characteristic of the accounting information after relevance. Credibility characteristic means that the information is free of bias and error, and it truly involves the characteristics and features intended to be highlighted about the subject matter being reported. (Hanan, 2003, 193).

The information will be considered credible if it is free from material error and bias, as well as when users can rely on to genuinely show what they are meant to demonstrate, thus, events must be addressed and presented in line with their nature and economic reality, not just their legal form. (Standards, 2009, 899).

Credibility characteristic consists of three sub-characteristics, not less important than the sub-characteristics of relevance; namely:

\section{1) Honesty in expression}

Honesty in expression characteristic means the existence of high degree of conformity between the measures (information) and the phenomena to be studied. Accounting information cannot be relied upon unless it honestly expresses what it is intended to express. Accounting information must reflect, realities honesty and integrity, the financial facts and events represented, where the value and accounting figures should conform with the financial and economic events measured and reported. (Hanan, 2003, 196).

Honesty in expression characteristic requires avoiding two types of bias, namely: (Hanan, 2003, 169).

1) Bias in measurement process: As in the application of the historical cost approach as a basis for measuring economic events. This historical measurement demonstrates bias in favor of the shareholders.

2) Bias of the measurement personnel: in this case, bias is either intentional, as in case of lacking honesty or unintentional as in case of lack of knowledge and experience.

\section{2) Verifiability}

Verifiability means that information has a specific significance and must be independent regardless of who prepares or uses it. (Wasfi, 2010, 32).

The verifiable and demonstrable characteristic means that the findings concluded by certain individual using certain methods of measurement and disclosure can be reached by someone else - independent person - using the same methods.

In that way, verification implies the meaning of the agreement of the accountants to measure specific economic event and how to report such event. So, verification does not mean the validity of method or method of measurement, but confirms the rules of measurement carefully applied without personal bias on the part of the individuals who conduct measurement.

\section{3) Impartiality}

Financial Accounting Standards Board defines bias in the measurement process as "the tendency of the measurement to happen what it expresses in a side more than the other side, rather than as equal potential event on both sides".

Impartiality means the lack of choosing accounting policies that lead to useful information to specific party of the concerned parties or interested party in accounting information over another party/ parties. The information must be realistic and unbiased. (Hammad, 2000, 50).

The researchers believe, through the presentation of the concept of reliability, that reliability must be available in the information reflected in the financial statements and reports, as a prerequisite which should be available in the information, so as the information users can rely on in taking and rationalizing their decisions, not matter of what type of decision. Accounting information must be credible, reliable and relevant to the decision in question. Two characteristics, relevance and credibility, must be available in the accounting information contained in the financial statements and reports in order to increase their quality and usefulness to the users, in particular the internal auditors. Once the accounting information does not have these two characteristics, they will be useless to 
users.

\section{Research Community and Sample}

The community of this study consists of all the commercial banks in Jordan excluded the Islamic ones. They reached 13 banks. The sample of this study consists of internal auditors in all the Jordanian commercial banks who received the questionnaire. Table 1 shows the name of banks and the number of questionnaires distributed and collected.

Table 1. The name of the Jordanian banks listed in Amman Stock Exchange, which represent the sample of the study

\begin{tabular}{lcccc}
\hline \multicolumn{1}{c}{ Bank name } & $\begin{array}{c}\text { Total number of } \\
\text { internal auditors }\end{array}$ & $\begin{array}{c}\text { Number of questionnaires } \\
\text { distributed }\end{array}$ & $\begin{array}{c}\text { Number of questionnaires } \\
\text { collected and subject to analysis }\end{array}$ & Percent \% \\
\hline Arab Bank & 15 & 15 & 12 & $\% 80$ \\
Housing Bank & 12 & 12 & 10 & $\% 83$ \\
Cairo Amman Bank & 13 & 13 & 10 & $\% 77$ \\
Jordan Bank & 9 & 9 & 8 & $\% 89$ \\
Jordan Kuwait Bank & 8 & 9 & 9 & $\% 100$ \\
Total & 57 & 57 & 49 & $\% 86$ \\
\hline
\end{tabular}

\section{Data Presentation and Hypotheses Testing}

Table 2. The analysis of the views of the study community members on the effect of the internal audit procedures on the accounting information quality in the financial reports of the Jordanian commercial banks

\begin{tabular}{|c|c|c|c|c|}
\hline Ser. & Variable & $\begin{array}{c}\text { Arithmetic } \\
\text { mean }\end{array}$ & $\begin{array}{l}\text { Standard } \\
\text { deviation }\end{array}$ & $\begin{array}{c}\text { Agreement } \\
\text { degree }\end{array}$ \\
\hline 1 & $\begin{array}{l}\text { Jordanian commercial banks rely on the planning of the audit to reduce the risk } \\
\text { of auditing to obtain reasonable assurance about the adequacy and relevance of } \\
\text { evidence to support its findings. }\end{array}$ & 3.71 & .780 & High \\
\hline 2 & $\begin{array}{l}\text { Jordanian commercial banks adopt certain procedures to achieve the verification } \\
\text { and evaluation function for compliance and include all financial events in the } \\
\text { accounting and financial records. }\end{array}$ & 3.29 & 0.95 & Average \\
\hline 3 & $\begin{array}{l}\text { The ultimate objective of the internal auditor's report, as a product of the } \\
\text { verification, testing and evaluation processes, is to provide the information to } \\
\text { decision makers on time. }\end{array}$ & 2.37 & 0.71 & Average \\
\hline 4 & $\begin{array}{l}\text { The ultimate objective of the internal auditor's report, as a product of the } \\
\text { verification, testing and evaluation processes, is to provide the predictive } \\
\text { capacity to the decision makers. }\end{array}$ & 3.68 & 0.79 & Average \\
\hline 5 & $\begin{array}{l}\text { Planning audit activity is a need to develop objectives, identify the scope of } \\
\text { work, and obtain sufficient information to form a background on activities to be } \\
\text { audited. }\end{array}$ & 3.90 & 0.75 & Average \\
\hline 6 & $\begin{array}{l}\text { Internal audit is a feedback tool, its outputs are inputs re-operated by the senior } \\
\text { management to produce new recommendations that positively affect the related } \\
\text { processes and activities. }\end{array}$ & 3.43 & 0.79 & Average \\
\hline & General average and its standard deviation & 3.26 & 0.76 & Average \\
\hline
\end{tabular}

Table 2 above shows that the answers of respondents were positive on the above paragraphs. The degree of agreement for some paragraphs ranged (2.34 - less than 3.67) and (3.68 to 5) for other paragraphs according to the scale adopted in the study. The standard deviation was acceptable for the above paragraphs, which indicates some agreement and consistency among the views of the research community members on the impact of internal audit on the quality of accounting information in the financial statements of the Jordanian commercial banks.

The table indicates that the trends of the respondents were positive in general towards the above-mentioned paragraphs because their arithmetic mean is greater than the mean of the measurement tool (3.0). The general average was (3.26) which reflect high degree according to the scale adopted in the study. In addition to the above, 
it is noted that the paragraphs No. (5), stating "Planning audit activity is a need to develop objectives, identify the scope of work, and obtain sufficient information to form a background on activities to be audited" obtained the highest degree of agreement with arithmetic mean reached (3.90). Paragraph (6), which states "Internal audit is a feedback tool, it outputs are inputs re-operated by the senior management to produce new recommendations that positively affect the related processes and activities" obtained the lowest degree of agreement, with arithmetic mean reached (2.37). The researchers believe that these findings indicate that there must be audit procedures leading to the production of reliable data and information for the parties interested in the financial reports of the Jordanian commercial banks.

\subsection{Testing Hypotheses}

\subsubsection{First Hypothesis}

HO1: There is no impact statistically significant of the internal audit procedures on the credibility of accounting information set in the financial reports of the Jordanian commercial banks.

The hypothesis has been tested through six (6) questions. Table 3 shows the answers on the questions of first variable of this study, the arithmetic mean and standard deviation in addition to the degree of agreement. The results were as follows:

Table 3. Analysis of the views of the community members on the lack of a statistically significant impact of internal audit procedures on the credibility of accounting information contained in the financial reports of Jordanian commercial banks

\begin{tabular}{clccc}
\hline Ser. & \multicolumn{1}{c}{ Variables } & $\begin{array}{c}\text { Arithmetic } \\
\text { mean }\end{array}$ & $\begin{array}{c}\text { Standard } \\
\text { deviation }\end{array}$ & $\begin{array}{c}\text { Degree of } \\
\text { agreement }\end{array}$ \\
\hline 7 & $\begin{array}{l}\text { Jordanian commercial banks adopt their own accounting procedures leading to the } \\
\text { production of reliable data and information. }\end{array}$ & 3.11 & .580 & High \\
8 & $\begin{array}{l}\text { Jordanian commercial banks adopt their own accounting procedures leading to the } \\
\text { production of impartial data and information by the measuring person. }\end{array}$ & 3.49 & 0.85 & Average \\
& $\begin{array}{l}\text { Jordanian commercial banks adopt their own accounting procedures leading to the } \\
\text { production of impartial data and information by the measurement tool. }\end{array}$ & 3.32 & 0.74 & Average \\
10 & $\begin{array}{l}\text { Jordanian commercial banks adopt their own accounting procedures leading to the } \\
\text { production of free of common bias data and information. }\end{array}$ & 3.38 & 0.94 & Average \\
11 & $\begin{array}{l}\text { Jordanian commercial banks adopt their own accounting procedures leading to } \\
\text { produce data and information that can be verified. }\end{array}$ & 3.90 & 0.65 & Average \\
12 & $\begin{array}{l}\text { Jordanian commercial banks adopt their own accounting procedures leading to the } \\
\text { production of credible data and information by users. }\end{array}$ & .342 & 0.74 & Average \\
& General Average and its standard deviation & $\mathbf{3 . 3 6}$ & $\mathbf{0 . 7 9}$ & High \\
\hline
\end{tabular}

Table 3 above shows that the responses of the respondents were positive to the above paragraphs, as reached full degree of agreement for some paragraphs (2.34 - less than 3.67) and others between (3.68 - 5.0), according to the scale adopted in the study. The standard deviation is also acceptable for the above paragraphs. This indicates some agreement and consistency in the opinion of the members of the study community on the importance of the impact of the credibility of the data and information contained in the financial reports of Jordanian commercial banks.

The table also indicates that the trends of the respondents were positive in general towards the above-mentioned paragraphs because their arithmetic mean is greater than the mean of the measurement tool (3.0). The general average was (3.36) which reflect high degree according to the scale adopted in the study. In addition to the above, it is noted that the paragraphs No. (11), stating "Jordanian commercial banks adopt their own accounting procedures leading to produce data and information that can be verified" obtained the highest degree of agreement with arithmetic mean reached (3.90). Paragraph (12), which states "Jordanian commercial banks adopt their own accounting procedures leading to the production of credible data and information by users." obtained the lowest degree of agreement, with arithmetic mean reached (2.34). The researchers believe that these findings indicate that there must be audit procedures leading to the production of reliable data and information for the parties interested in the financial reports of the Jordanian commercial banks. 


\section{Testing First Hypothesis}

HO1: There is no impact statistically significant of the internal audit procedures on the credibility of accounting information in the financial reports of the Jordanian commercial banks.

HA1: There is impact statistically significant of the internal audit procedures on the credibility of accounting information in the financial reports of Jordanian commercial banks.

Table 4. The simple linear regression

\begin{tabular}{cccccccc}
\hline T Calculated & T tabular & SIG T & Result of Null Hypothesis & R & R2 & Reliability & b \\
\hline 4.496 & 1.96 & 0.00 & Rejected & 0.301 & 0.901 & 4.107 & 0.216 \\
\hline
\end{tabular}

The simple regression test has been used to test hypotheses in general. Out examination to the results of analysis in the above table shows that (T) calculated value is (4.496) higher than the its tabular value. According to the decision rule stating that: The Hypothesis (HO) is acceptable if the (T) calculated value less than the tabular value, and the significance value higher than (0.05), and reject the (HO) if the (T) calculated value higher than the tabular one and the (SIG) value was less than (0.05). So, we reject the alternative hypothesis (HA). This means that, according to the above-mentioned results that there is impact statistically significant for the internal audit on the credibility of the accounting information contained in the financial reports of the Jordanian commercial banks.

\subsubsection{The Second Hypothesis}

HO2: there is no impact statistically significant for the internal audit procedures on the relevance of the accounting information contained in the financial reports of the Jordanian commercial banks.

This hypothesis has been tested by (6) questions. Table 5 shows the answers to the questions of the variable II of this study, the arithmetic mean and standard deviation, in addition to the degree of agreement. The results were as follows:

Table 5. Analysis of the views of the community members on the lack of a statistically significant impact of internal audit procedures on the relevance of accounting information contained in the financial reports of Jordanian commercial banks

\begin{tabular}{|c|c|c|c|c|}
\hline Ser. & Variables & $\begin{array}{c}\text { Arithmetic } \\
\text { mean }\end{array}$ & $\begin{array}{l}\text { Standard } \\
\text { deviation }\end{array}$ & $\begin{array}{r}\text { Degree of } \\
\text { agreement }\end{array}$ \\
\hline 13 & $\begin{array}{l}\text { Jordanian commercial banks adopt their own accounting procedures leading } \\
\text { to the production of predictive data and information }\end{array}$ & 3.42 & 0.55 & High \\
\hline 14 & $\begin{array}{l}\text { Jordanian commercial banks adopt their own accounting procedures leading } \\
\text { to the production of predictive data and information to correct past } \\
\text { expectations. }\end{array}$ & 2.33 & 0.616 & Average \\
\hline 15 & $\begin{array}{l}\text { Jordanian commercial banks adopt their own accounting procedures leading } \\
\text { to the production of predictive data and information to rationalize decisions. }\end{array}$ & 3.07 & 0.600 & Average \\
\hline 16 & $\begin{array}{l}\text { Jordanian commercial banks adopt their own accounting procedures leading } \\
\text { to the production of data and information obtained in a timely manner. }\end{array}$ & .054 & 0.87 & Low \\
\hline 17 & $\begin{array}{l}\text { Jordanian commercial banks adopt their own accounting procedures leading } \\
\text { to the production of data and information having feedback }\end{array}$ & 3.15 & 0.489 & Average \\
\hline \multirow[t]{2}{*}{18} & $\begin{array}{l}\text { Jordanian commercial banks adopt their own accounting procedures leading } \\
\text { to the production of data and information able to take a decision. }\end{array}$ & 3.05 & 0.586 & Average \\
\hline & General Average and its standard deviation & 3.32 & 0.43 & Average \\
\hline
\end{tabular}

Table 5 above shows that the responses of the respondents were positive to the above paragraphs, as reached full degree of agreement for some paragraphs (2.34 - less than 3.67) and other paragraphs between (3.68 - 5.0). Question No (8) obtained the lowest degree of agreement according to the scale adopted in the study. The standard deviation is also acceptable for the above paragraphs. This indicates some agreement and consistency in the opinion of the members of the study community on the importance of the impact of relevance of the data and information contained in the financial reports of Jordanian commercial banks. 
The above table also indicates that the trends of the respondents were positive in general towards the above-mentioned paragraphs because their arithmetic mean is greater than the mean of the measurement tool (3.0). The general average was (3.32) which reflect average degree of agreement according to the scale adopted in the study. In addition to the above, it is noted that the paragraph No. (16), stating "Jordanian commercial banks adopt their own accounting procedures leading to the production of data and information obtained in a timely manner" obtained the highest degree of agreement with arithmetic mean reached (4.05). Paragraph (14), which states "Jordanian commercial banks adopt their own accounting procedures leading to the production of predictive data and information to correct past expectations" obtained the lowest degree of agreement, with arithmetic mean reached (2.33). The researchers believe that these findings indicate that it is a must to adopt accounting procedures leading to the production of relevant data and information able to predict now and in future.

\section{Testing the Second Hypothesis}

HO2: there is no impact statistically significant for the internal audit procedures on the relevance of the accounting information contained in the financial reports of the Jordanian commercial banks.

HA2: there is no impact statistically significant for audit procedures on the relevance of the accounting information contained in the financial reports of the Jordanian commercial banks.

Table 6. The simple linear regression for testing the second hypothesis

\begin{tabular}{cccccccc}
\hline T Calculated & T tabular & SIG T & Result of Null Hypothesis & R & R2 & Reliability & b \\
\hline 21.299 & 1.96 & 0.00 & Rejected & 0.831 & 0.961 & 0.692 & 0.857 \\
\hline
\end{tabular}

The simple linear regression test has been used to test the validity of the hypothesis. Our examination to the computerized results shown in the above table that (T) calculated value is (21.299) higher than the its tabular value. According to the decision rule stating that: The Hypothesis (HO) is acceptable if the (T) calculated value less than the tabular value, and the significance value (SIG) higher than (0.05), and reject the (HO) if the (T) calculated value higher than the tabular one and the (SIG) value was less than (0.05). So, we reject the Null hypothesis and accept the alternative (HA) hypothesis. This means that, according to the above-mentioned results that there is an impact statistically significant for auditing on the relevance of accounting information contained in the financial reports of the Jordanian commercial banks.

\section{Results}

1) The internal audits, with all their procedures and control, play influential role in the process of producing financial reports in Jordanian commercial banks having the ability to effect on decision making in the Jordanian commercial banks.

2) The internal audits activities, with all their procedures and control, having impact on the production of reliable financial statements and report process in the Jordanian commercial banks, which can be relied upon making decision in the Jordanian commercial banks.

\section{Conclusion}

The results of the paper comply with the study conducted by Soda and Al-Chahadah (2017), in view of the importance of accounting information, relying on relevance and dependability and their impacts on performance evaluation in Jordanian Commercial Banks. In addition, the paper agrees with both studies conducted respectively by Lawrence et al. (2016) and Gras-Gil et al. (2012), due to the significance of internal auditing quality in creating financial reports in commercial banks. These reports are in harmony with accounting data properties maintained by international accounting standards. While Abbott included an additional condition to ascertain accounting information quality in financial reports, which is the independence of internal auditor.

\section{Recommendations}

1) The Jordanian commercial banks must adopt their own accounting procedures that lead to the production of data and information that have the predictive ability to correct the past expectations of investors, administrators, businessmen and financial analysts interested in the economics of Jordanian commercial banks.

2) Jordanian commercial banks must adopt their own accounting procedures that will lead to the production of reliable data and information for users and interested parties. 


\section{References}

Abbott, L. J., Brian, D., Susan, P., \& Gary, F. P. (2016). Internal Audit Quality and Financial Reporting Quality: The Joint Importance of Independence and Competence. Journal of Accounting Research, 54(1). https://doi.org/10.1111/1475-679X.12099

Abu, S., \& ABD al S. A. S. (2010). Integration of internal audit and external audit. Unpublished Master thesis in accounting, discussed and approved at the University of Algeria, Algeria.

Abu, Z., \& Afaf, I. (2006). A proposed strategy to improve the effectiveness of corporate governance in the Jordanian banking sector. PhD in Accounting, discussed and approved at Amman Arab University, Amman, Jordan.

Afifi, A. M. F. (2007). Obstacles to the work of the Internal Audit Units and the proposed mechanisms to increase their effectiveness, An applied analytical study on the Palestinian National Authority institutions in the Gaza Strip. Unpublished Master Thesis, Faculty of Commerce, Islamic University, Gaza, Palestine.

Al-Agha, N. S. (2015). The extent of application of well-known government auditing standards in the Office of Financial and Administrative Control of Palestine. Master Thesis in Accounting which was discussed and approved at the Islamic University, Gaza, Palestine.

Al-Aqeel, M. (2011). Quality of Accounting Information: Applied Study on Saudi stock companies during 1991-2009. General Administration Magazine, (3).

Al-Daya, M. (2009). The impact of using accounting information systems on the quality of the financial statements in service sector in GHaza Strip (A field study). Unpublished master thesis, Islamic University, Gaza.

Al-Mar'ie, N. T. (2009). The Role of the Audit Committee in Improving the Internal Audit Function in Jordanian Insurance Companies: A Field Study. Unpublished Master thesis, Faculty of Economic, Administrative and Financial Studies, Jadra University, Irbid, Jordan .

Al-Sawafiri, F., Mahmoud, M. S., \& Kamel, M. (2002). Moder Trends in the Control and Internal Auditing. New University House, Alexandria, Egypt.

Al-Wardat, K. A. (2014). Internal Audit Guide in accordance with international standards issued by IIA (1st ed.). Al-Warraq for Publishing and Distribution, Amman, Jordan.

Arens, A., \& Loeb, B. J. (2003). Auditing: An Integrated Approach. Audit, 379.

DeLone, W. H., \& McLean, E. R. (2008). The DeLone and McLean model of information systems success: A ten-year update. Journal of Management Information Systems, 19(4), 9-30.

Elaoud, A., \& Jarboui, A. (2017). Auditor specialization, and accounting information quality and investment efficiency. International Business and Finance, 42(C). https://doi.org/10.1016/j.ribaf.2017.07.006

Fowzia, R. (2010). Co-operation between Internal and External Auditors: A Comparative Study on Nationalized and Foreign Banks in Bangladesh. World Journal of Management, 2(2), 27.

Gras, E., Salvador, M. H., \& Domingo, G. P. de L. (2012). Internal audit and financial reporting in the Spanish banking industry. Managerial Auditing Journal, 27(8).

Hammad, T. A. (2000). Financial Reports (Principles of Preparation, Presentation and Analysis). University Press House, Alexandria, Egypt.

Hanan, R. H. (2003). The Contemporary Accounting Model. Dar Wael Publishing, Amman, 2003.

IFAC. (2010). Publications of the International Standards for Quality Control, Auditing, Auditing and Other Assurance and Related Services. Translation of the Arab Society of Certified Accountants, Amman, Jordan.

International Accounting Standards. (2009). Issued by the Arab Society of Certified Public Accountants (IASB), IAS 1.

Kiso, D. E., Weygandt, J. J., \& Warfield, T. D. (2005). Intermediate Accounting (12th ed.). Wiley \& Sons, Inc.

Matar, M. (2007). Financial Accounting: Problems of Measurement, Disclosure and Analysis. Part II. Amman, Al Falah Library for Publishing and Distribution.

Nadhir, S. (2014). Accounting Disclosure in the financial accounting system and its impact on the quality of information. Master's thesis, University of Qasidi, Merbah, Wargla, Algeria.

Richard, S. et al. (2006). Accounting Theory. Arabization by Khaled Ali Ahmed Kageji, Ibrahim Mohamed Fal, Dar Al Mareekh Publishing, Riyadh. 
Soda, M. Z., Abdul, R. Al-Chahadah, \& Rania, Al O. (2017). The Balanced Scorecard as a Strategic Introduction to the Commercial Banks Performance Assessment in Jordan. International Journal of Applied Business and Economic Research, 15(19).

Wasfi, A. F. Abu al-Makarem, \& Sameer, K. M. (2010). Financial Accounting - Theoretical Approach and Short-term assessment of Assets (p. 28). University Publishing House, Alexandria.

\section{Copyrights}

Copyright for this article is retained by the author(s), with first publication rights granted to the journal.

This is an open-access article distributed under the terms and conditions of the Creative Commons Attribution license (http://creativecommons.org/licenses/by/4.0/). 